\title{
How Projects in Special Collections Help Students Find Their Faith and Voice
}

Carisse Mickey Berryhill, Abilene Christian University Bob Turner, Harding School of Theology

ABSTRACT In this session, Bob Turner and Carisse Berryhill share their experience of using archives as a component of a class in Stone-Campbell History at Harding School of Theology. Berryhill teaches the course as an adjunct professor. As the library director, Turner has partnered with her to receive items that students wish to study and then donate to the Meredith Restoration History Archive.

This project began as a collaboration between Bob Turner and Carisse Berryhill that was focused on how they could strengthen special collections of their religious heritage (Churches of Christ) through a pedagogical innovation within Berryhill's Stone-Campbell History course. The basic premise is that the student project of the course is to obtain an archival piece, study it, write about it, and deposit that piece into the Meredith Restoration History Archive at Harding School of Theology.

The project has a few aims:

1) By thinking about how students might contribute to the archives, they become aware of archives, special collections, and forms of documentation beyond the published historical works found in the stacks.

2) By contributing to special collections, students participate in a two-way relationship between the library and the student. While we affirm the importance of curated programming by libraries/archives, we also recognize that there is tremendous value in allowing students to find their voice and story in the collections.

3) The experience orients the student not only to the product of history-writing, but also to the process of history-building. They see how small deposits can fund future research. They 
contribute to collections that will be useful to future historians.

During the presentation, Berryhill shared how students doing such projects not only found a connection with their religious heritage but perhaps experienced something more personal and transformative. They found their voice, faith, and story. They might see existing archives that feature their grandparents, but they might also contribute and study a piece that shows a side of their rigid childhood preacher that they had not personally witnessed. They witness players in Churches of Christ (a low church tradition) who rarely get into the history books. Further, since Churches of Christ lack a centralized headquarters/archive, schools such as Harding and Abilene Christian are on the frontlines of not only telling the movement's history, but also collecting it.

During the presentation, Berryhill and Turner shared some of the lessons they've learned during the past few years of offering the project:

- Small collections are often preferable. This gives the students an opportunity to have the dual experience of contributing to the special collections as well as doing a deep dive into a particular piece in a way that they wouldn't be able to with a large corpus.

- The better projects document small stories in a detailed way rather than documenting large subjects in a generic way. Some of the best projects are a one-page letter, a significant photo, or a small handwritten journal.

- Projects help Special Collections fill needs. Churches of Christ don't have a strong tradition of documenting the ministry of women. This project allows students to contribute to this gap by conducting oral histories of prominent women, for example. Some of the best projects are historical pieces/episodes from historically Black Churches of Christ.

- Students need instruction on what this means. While we want to encourage creativity, it's really important to share the vision for the projects (and possibly show projects from earlier semesters). 